\title{
PENGEMBANGAN PEMBELAJARAN DALAM MEMBANGUN PEMAHAMAN RELASIONAL SISWA MELALUI PENDEKATAN PMRI MATERI RELASI FUNGSI
}

\author{
${ }^{1}$ Rajibah Hanifah, ${ }^{2}$ Anton Noornia, ${ }^{3}$ Pinta Deniyanti Sampoerno \\ ${ }^{1,2,3}$ Universitas Negeri Jakarta, Jl. Rawamangun Muka, RT.11/RW.14, Rawamangun, Kec. Pulo Gadung, Kota \\ Jakarta Timur, Daerah Khusus Ibukota Jakarta 13220, Indonesia \\ e-mail: han.mouri@gmail.com
}

\begin{abstract}
Abstrak
Peserta didik di SMA Cakra Buana Depok mengalami kesulitan dalam memahami konsep materi relasi dan fungsi. Masalah pemahaman konsep relasi dan fungsi ini perlu diatasi. Oleh sebab itu penelitian ini bertujuan mengembangkan pembelajaran relasi dan fungsi dengan menunjukkan aktivitas dan prosedur dalam membangun pemahaman relasional siswa menggunakan konteks seperti Pemilihan Kepala Daerah (Pilkada) dengan pendekatan Pendidikan Matematika Realistik Indonesia. Penelitian dilaksanakan di kelas X SMA Cakra Buana Depok. Metode yang digunakan adalah design research yang terdiri atas tiga fase yaitu preparing for the experiment, experimenting in the classroom, dan conducting retrospective analysis. Penelitian ini terdiri dari 4 pertemuan dengan subjek penelitian 6 siswa yang memiliki kemampuan awal yang heterogen. Teknik pengumpulan data yang digunakan yaitu pensil dan kertas, wawancara, serta perekaman video. Instrumen penelitian dalam pengumpulan data adalah hipotesis lintasan belajar, lembak aktivitas, lembar kerja, lembar observasi, lembar wawancara dan tes kemampuan pemahaman relasional. Hasil analisis retrospektif menunjukkan bahwa secara keseluruhan penggunaan konteks yang tepat sesuai materi serta peran aktif siswa dan guru dalam pembelajaran sesuai dengan karakteristik PMRI dapat menumbuhkan dan membangun pemahaman relasional siswa pada materi relasi dan fungsi.
\end{abstract}

Kata Kunci: design research, PMRI, pilkada, pemahaman relasional, relasi dan fungsi.

\begin{abstract}
Students of Senior High School Cakra Buana Depok have problems to understand the mathematics concept of relation and function well. In order to solve the problems, need instructional design in which are children developing relational understanding concepts of relation and function. This study aims to develop local instructional theory in order to establish students' relational understanding of relations and functions concepts using context election day and PMRI approach. The method used in this study is design research of which stages are preparing for the experiment, experimenting in the classroom, and conducting retrospective analysis. This study consisted of four sessions with six research subjects who have different ability (heterogent). The data collected using student's written work, interviews also video recording. The instruments of this study consist of hypothetical learning trajectories, student's activity sheets, worksheets, observations sheets, interview sheets and relational understanding concepts tests. The results from retrospective analysis show that using the right contexts in the implementation of PMRI are emerging and developing student's relational understanding of relation and function.
\end{abstract}

Keywords: design research, PMRI, elections day, relational understanding, relation and funtion

\section{PENDAHULUAN}

Kemampuan memahami, menerapkan, menganalisis dan mengevaluasi pengetahuan faktual terkait penyebab fenomena kejadian dalam kehidupan sehari-hari merupakan kompetensi inti dalam pembelajaran matematika di tingkat pendidikan menengah (kelas X-XII SMA) yang ditetapkan dalam Permendikbud Nomor 21 Tahun 2016. Pemahaman mencakup kemampuan menangkap arti dan makna tentang hal yang dipelajari. Pemahaman terdiri dari dua jenis yaitu 
pemahaman instrumental dan pemahaman relasional. Memahami konsep matematika secara instrumental bisa dilihat dari kemampuannya dalam menghitung dan mengaplikasikan secara prosedur yang bersifat rutin tapi tidak mengerti proses matematisasi yang berada dibalik aturan tersebut (Chubb, 2016). Tetapi peserta didik diharapkan mampu memiliki pemahaman realasional dengan memahami konsep atau prinsip ke dalam pikiran siswa sehingga dapat mengaitkan atau menjelaskan hubungan antar konsep serta mengaplikasikan konsep tersebut dalam kehidupan sehari-hari.

Relasi dan fungsi merupakan salah satu materi yang dipelajari pada pelajaran matematika di sekolah menengah atas (Permendiknas No.22 Tahun 2016). Masih sedikit siswa yang mampu menyerap pemahaman apa yang disampaikan guru mengenai materi relasi dan fungsi (You, 2006). Kesulitan ini karena siswa hanya menghafal rumus-rumus yang diberikan guru dan menghitung secara matematis saja. Hal ini kegiatan pembelajaran yang tidak memberikan kesempatan bagi siswa untuk mengembangkan kemampuan siswa dalam pemecahan masalah, penalaran, relasional dan komunikasi matematis.

Kesulitan terkait materi relasi dan fungsi juga dialami siswa SMA Cakra Buana yang terlihat pada hasil observasi yang menyatakan sebanyak 38\% siswa mengatakan bahwa materi relasi dan fungsi termasuk tiga materi tersulit di kelas X. Siswa menganggap sulit materi relasi dan fungsi karena siswa kurang mengerti rumus-rumus yang diberikan digunakan untuk apa dalam kehidupan sehari-hari. Kesulitan tersebut terlihat saat siswa menyelesaikan soal cerita tentang tarif taksi. Siswa belum bisa merumuskan tarif taksi berdasarkan soal cerita. Hal ini menunjukkan bahwa siswa belum mampu menunjukkan pemahaman relasional dalam menyelesaikan soal yang diberikan karena tidak bisa menghubungkan materi yang didapatkan dengan keadaan yang nyata di kehidupan sehari-hari.

Kesulitan siswa SMA Cakra Buana terkait materi relasi dan fungsi perlu diatasi karena akan berdampak ke materi matematika yang lainnya. Untuk mengatasi kesulitan tersebut maka perlu dilakukan kegiatan pembelajaran yang mempersiapkan siswanya untuk menemukan dan memahami konsep dan permasalahan pemahaman matematika salah satunya adalah dengan pendekatan Pendidikan Matematika Realistik Indonesia (PMRI). PMRI bertumpu pada realita dalam kehidupan keseharian siswa yang telah diselaraskan dengan kondisi budaya, geografi dan kehidupan masyarakat Indonesia pada umumnya (Wijaya, 2012; Hadi, 2017). Konteks kehidupan masyarakat Indonesia yang berhubungan dengan materi relasi dan fungsi adalah Pilkada. Konteks tersebut tidak asing bagi siswa SMA Cakra Buana karena daerah tempat siswa berada sedang melaksanakan Pilkada yang beritanya sangat masif di media cetak (baliho di tepi jalan) maupun elektronik (radio, televisi dan media online). Untuk mengatasi kesulitan siswa dalam memahami konsep maka perlu diadakan aktivitas pembelajaran lain salah satunya dengan pendekatan PMRI.

Prima, Vol. 3, No. 2, Juli 2019, 103-115. 
Penelitian yang sudah menerapkan pendekatan PMRI untuk masalah yang terjadi di kelas matematika dan menghasilkan hasil yang positif antara lain Oktaria (2015), Mulyana (2015) dan Jamaliah (2016). Penelitian ini bertujuan mengembangkan pembelajaran guna membangun pemahaman relasional siswa khususnya pada pokok bahasan relasi dan fungsi di kelas X SMA Cakra Buana Depok dengan pendekatan PMRI diharapkan dapat menjadi solusi atas masalah yang terjadi.

\section{METODE PENELITIAN}

Design research atau developmental research merupakan suatu penelitian yang intinya terbentuk dari eksperimen mengajar di kelas yang berpusat pada pengembangan urutan instruksional dan teori instruksional lokal yang mendukungnya untuk menghasilkan teoriteori baru, artefak, dan praktek-praktek yang dapat menjelaskan dan berpotensi mempengaruhi proses belajar dan mengajar yang dibuat secara alami (Gravemeijer dan Cobb, 2004; Van den Akker dkk, 2006). Design research terdiri dari tiga tahapan yaitu preparing for the experiment, experimenting in the classroom, dan conducting retrospective analysis. Penjelasan dari ketiga tahapan tersebut adalah sebagai berikut:

\section{Preparing for The Experiment}

Tahap awal yang dilakukan pada tahapan desain permulaan adalah membuat Hypothetical Learning Trajectory (HLT) atau Hipotesis Lintasan Belajar (HLB). HLB terdiri dari tiga komponen yaitu: menjelaskan tujuan pembelajaran matematika, membuat perencanaan instruksi aktivitas siswa dan alat-alat yang dibutuhkan dalam pembelajaran serta membuat hipotesis proses berpikir siswa yang memuat antisipasi tentang berbagai kemungkinan yang akan terjadi selama proses pembelajaran.

\section{Experimenting in The Classroom}

Tahap kedua adalah mengujicobakan apa yang telah dibuat dalam HLB ke aktivitas pembelajaran di kelas. Data-data penelitian dikumpulkan selama proses ekperimen pengajaran ini. Semua data yang diperoleh disusun sesuai urutan kegiatan untuk memudahkan analisis pada tahap selanjutnya.

3. Conducting Retrospective Analysis.

Kegiatan pada tahap ini adalah membandingkan HLB dengan proses kegiatan belajar siswa di kelas yang sesungguhnya. Analisis tinjauan dilakukan berdasarkan data yang diperoleh yang telah diurutkan sesuai urutan kegiatan pembelajaran. Fokus analisisnya 
dibatasi pada pertanyaan penelitian yang diajukan sehingga dapat menjawab petanyaan penelitian tersebut.

\section{HASIL DAN PEMBAHASAN}

\section{Hasil Eksperimen Mengajar}

Hasil eksperimen mengajar merupakan bagian yang menjelaskan atau mendeskripsikan secara terperinci mengenai proses pembelajaran yang dilakukan dengan menggunakan pendekatan PMRI di kelas. Pada tahap ini dilakukan analisis retrospektif terhadap proses pembelajaran yang dilakukan dalam setiap pertemuan sehingga dapat diketahui berbagai perkembangan dan kekurangan yang terjadi dalam setiap pertemuan. Tujuan utama analisis retrospektif adalah untuk mengetahui sejauh mana kontribusi dari pengembangan teori instruksional lokal. Analisis retrospektif difokuskan pada aktivitas siswa yang dilakukan, respons siswa terhadap proses pembelajaran, peran guru dalam memfasilitasi siswa pada proses pembelajaran dengan menggunakan pendekatan PMRI, aktivitas diskusi kelompok, dan proses pemahaman relasional siswa yang dilakukan oleh siswa baik secara individu maupun berkelompok.

\section{a. Pertemuan Pertama}

Aktivitas pada pertemuan pertama yaitu menonton video Partai Pengusung Bursa Pilkada DKI Jakarta 2017. Aktivitas awal ini diharapkan siswa dapat menemukan konsep relasi dan fungsi berdasarkan konteks yang diberikan melalui video yang ditayangkan. Kemudian dilanjutkan dengan diskusi dan mengerjakan lemar aktivitas yang terlihat pada gambar 1 .

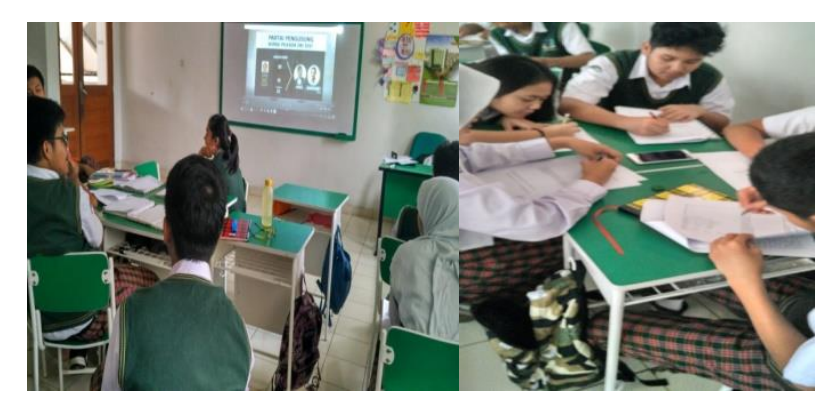

Gambar 1. Aktivitas Menonton Video dan Diskusi Siswa

Aktivitas pertama ini siswa berhasil menemukan konsep relasi dan fungsi dari konteks Pilkada. Siswa berhasil mengembangkan pola pikirnya dengan diskusi antar siswa dalam kelompok maupun diskusi dengan guru sesuai dengan kemampuan awal yang telah dimiliki siswa sebelumnya. Dari hasil diskusi siswa, siswa berhasil membuat model of dari diagram 
panah partai pengusung dan pasangan cagub-cawagub, pasangan cagub-cawagub yang diusung partai pengusung menjadi model for pada konsep relasi dan fungsi seperti telihat pada tabel 1 berikut,

Tabel 1. Model of dan Model for Konsep Relasi dan Fungsi

\begin{tabular}{|c|c|c|c|}
\hline \multirow{5}{*}{ 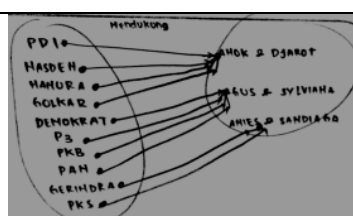 } & \multicolumn{3}{|c|}{ 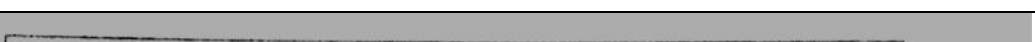 } \\
\hline & Ciri-ciri gambar pada soal nomor 2 & Ciri-ciri gambar pada soal nomor 4 & \\
\hline & domainnyuoens partas & domarnma berisi cagub & \\
\hline & Kodomainya eris cagub & codomainth beríh partai & \\
\hline & domuin himpunan 1 berisi 4 anggotion & Kodomain himpunan 1 bens, 4 argeoin & \\
\hline namen & domuin nimivan 2 beris 4 angyoth & $11 \quad 1$ bens 4 urgotr & \\
\hline & domain nimiunan? weris t wagolis & 113 beriti 2 angenath & \\
\hline & Setrap domunt uryu memlixi 1 Honda purom & 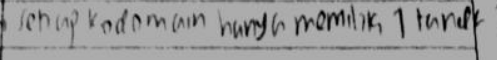 & Paral \\
\hline Model of & & Model for & \\
\hline
\end{tabular}

Konteks Pilkada berhasil menjembatani pengetahuan siswa dari tahap informal menjadi tahap formal melalui interaktivitas berupa diskusi antara siswa dengan siswa ataupun antara siswa dengan guru. Siswa berhasil menemukan konsep sifat relasi dan fungsi berdasarkan konteks Pilkada. Sehingga tujuan penelitian dari pertemuan ini tercapai dengan baik.

\section{b. Pertemuan Kedua}

Aktivitas pada pertemuan kedua memuat serangkaian aktivitas untuk menemukan konsep sifat fungsi injektif dari suku-suku yang berasal dari pulau Sumatera. Kegiatan tersebut merupakan kegiatan mengeksplorasi konsep relasi dan fungsi yang digunakan untuk mengingatkan kembali siswa pada konsep fungsi sekaligus berguna untuk menganalisis kemampuan awal tentang fungsi. Siswa diminta untuk mengamati peta pulau Sumatera beserta daftar nama-nama suku yang berasal dari pulau Sumatera lalu mendiskusikannya dalam lembar aktivitas siswa. Siswa berhasil mengidentifikasi suku-suku yang berawal dari huruf T kemudian dipasangkan dengan provinsinya.

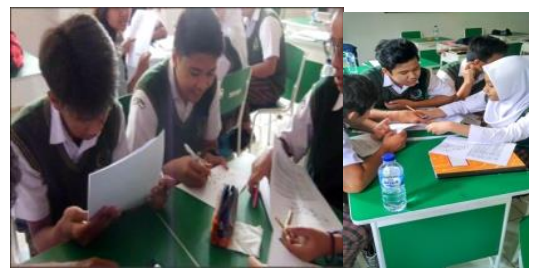

Gambar 2. Aktivitas Mengamati Nama Suku di Pulau Sumatera dan Diskusi 
Konteks suku-suku yang berawalan hutuf $\mathrm{T}$ yang berada di pulau Sumatera berhasil menjembatani siswa untuk menemukan konsep sifat fungsi injektif. Suku-suku yang berawalan huruf $\mathrm{T}$ di pulau Sumatera sebagai model of dapat menjembatani siswa dalam menemukan konsep sifat fungsi injektif sebagai model for. Interaktivitas antara siswa dengan siswa maupun siswa dengan guru terjalin dengan baik.

Tabel 2. Model of dan Model for Konsep Sifat Fungsi Injektif

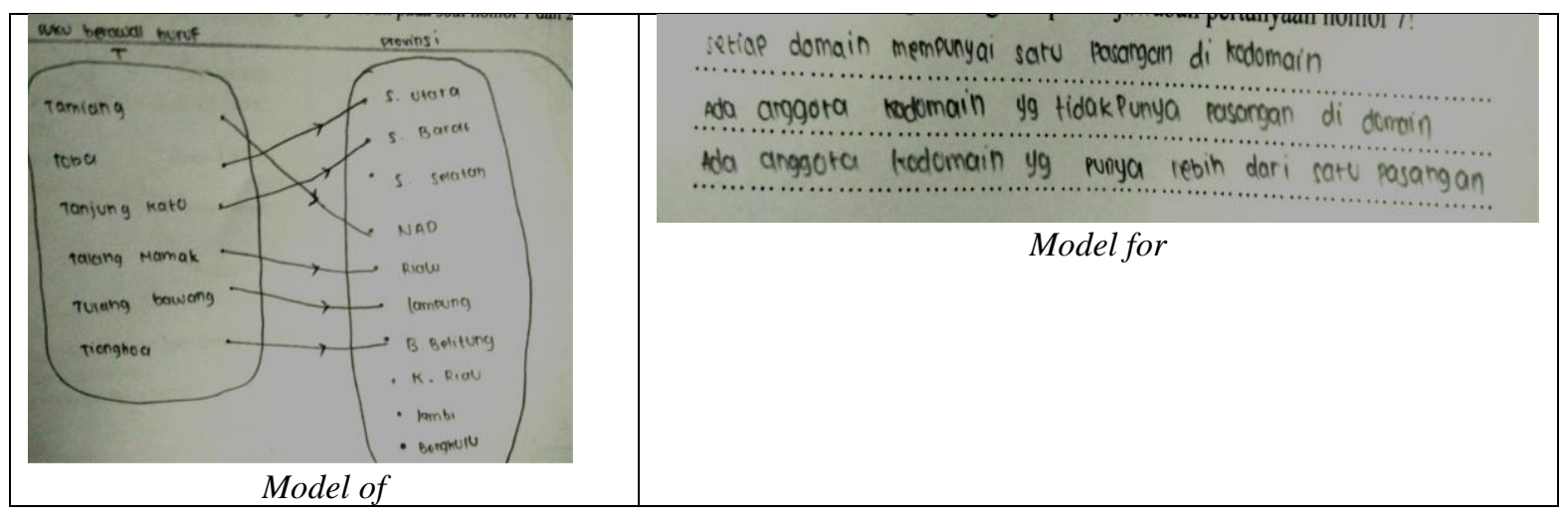

\section{c. Pertemuan Ketiga}

Pembelajaran pada pertemuan ketiga ini bertujuan untuk menemukan sifat fungsi surjektif. Konteks pembelajaran yang digunakan yaitu menggunakan peta dunia. Aktivitas mengamati peta dunia yang terdiri dari banyak nama negara yang mendiami benua yang ada di dunia. Dari aktivitas ini berlanjut dengan diskusi dan mengerjakan lembar aktivitas hingga siswa menemukan konsep fungsi surjektif.

Tabel 3. Model of dan Model for Konsep Sifat Fungsi Surjektif

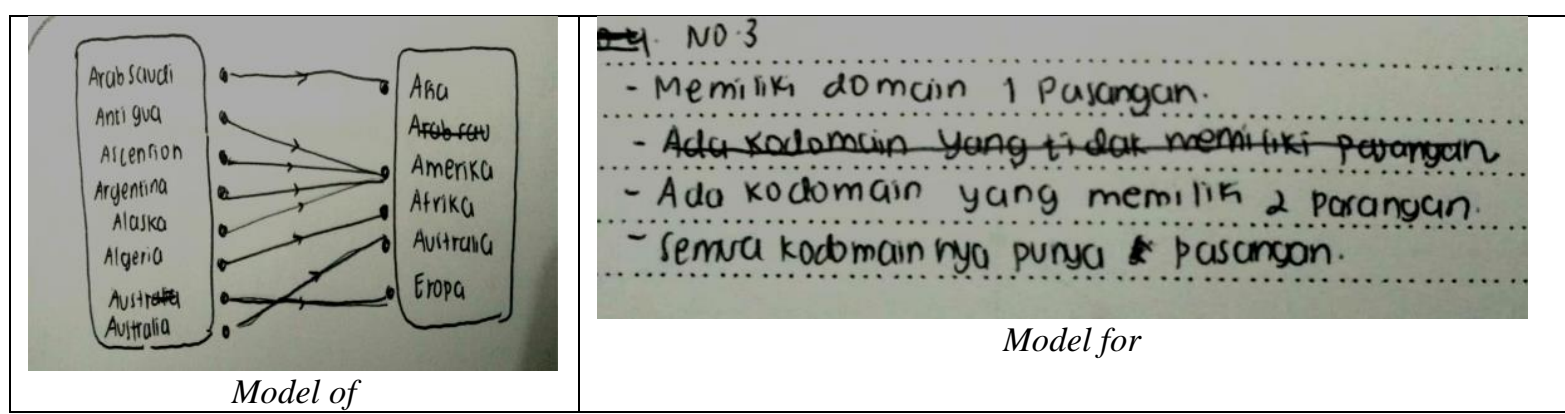

Konteks Peta Dunia dimana nama-nama negara berawalan huruf A dipasangkan dengan benua dimana letak negara tersebut berada. Konteks ini berhasil dengan siswa membuat diagram panah sebagai model of dan sifat-sifat yang dimiliki dari diagram panah tersebut menjadi model for untuk menemukan sifat fungsi surjektif.

Prima, Vol. 3, No. 2, Juli 2019, 103-115. 


\section{d. Pertemuan Keempat}

Pertemuan ini memuat aktivitas yang bertujuan untuk menemukan sifat fungsi bijektif. Konteks yang digunakan pada pertemuan ini adalah tentang jadwal pertandingan sepak bola liga Inggris. Hal ini bertujuan untuk mengetahui kemampuan pemahaman relasional siswa dalam menemukan sifat fungsi bijektif berdasarkan sifat fungsi injektif dan surjektif yang telah didapatkan siswa pada pertemuan sebelumnya. Kegiatan pada pertemuan keempat dimulai dengan konteks jadwal pertandingan liga Inggris melalui tayangan video dan mengamati gambar KTP. Aktivitas diisi dengan diskusi, mengerjakan lembar aktivitas, persentasi dan mengerjakan lembar aktivitas siswa sebagai penguatan konsep yang dipelajari.

Tabel 4. Model of dan Model for Konsep Sifat Fungsi Surjektif

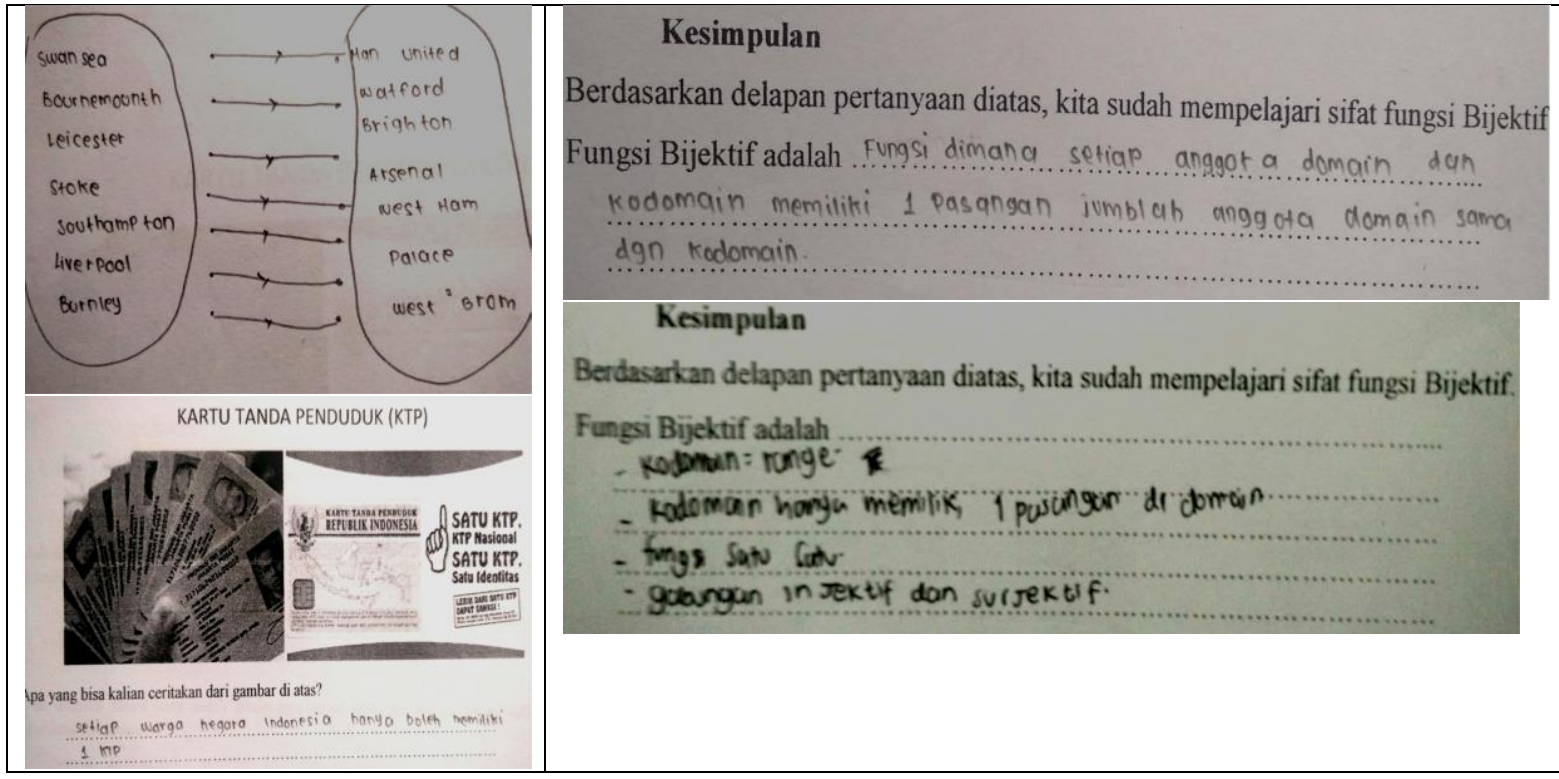

Seluruh aktivitas pada pertemuan keempat ini mengimplementasian karakteristik PMRI dimana digunakan konteks jadwal pertandingan sepak bola liga Inggris dan KTP yang merupakan hal realistik pada siswa. Dari konteks tersebut siswa akan terbantu saat membangun konsep sifat fungsi bijektif. Siswa diminta kembali untuk mengingat materi sebelumnya yaitu tentang sifat fungsi injektif dan sifat fungsi surjektif sebagai modal awal siswa. Jadwal pertandingan sepak bola Liga Inggris yang digambarkan siswa dalam bentuk diagram panah dan hasil mengamati KTP sebagai model of yang dapat menjembatani siswa dalam menemukan sifat fungsi bijektif sebagai model for. 


\section{e. Pertemuan Kelima}

Aktivitas pada pertemuan kelima yaitu siswa diminta untuk menyelesaikan soal pemecahan masalah yang berkaitan dengan relasi dan fungsi. Indikator dari pemahaman relasional menurut Skemp, mengacu pada indikator pemahaman konsep menurut Kilpatrick dan Findell (Riyanti, 2011), yaitu:

1. Kemampuan menyatakan ulang konsep yang telah dipelajari.

2. Kemampuan mengklarifikasi objek-objek berdasarkan dipenuhi atau tidaknya persyaratan yang membentuk konsep tersebut.

3. Kemampuan menerapkan konsep secara algoritma.

4. Kemampuan memberikan contoh dari konsep yang dipelajari.

5. Kemampuan menyajikan konsep dalam bentuk representasi matematika.

6. Kemampuan mengaitkan berbagai konsep (internal dan eksternal matematika).

Siswa diwawancarai terkait jawaban yang sudah ditulis siswa dalam lembar evaluasi. Dari hasil wawancara siswa, guru memperoleh informasi bagaimana siswa mengerjakan, bagaimana cara dia mengerjakan dan alasan apa dia menjawabnya.

\section{Analisis Subjek Penelitian (SP)}

\section{a. Analisis SP1}

SP 1 merupakan salah satu siswa yang tergolong dalam kategori siswa berkemampuan tinggi di dalam kelas. Hal ini dapat dilihat dari nilai raport siswa pada mata pelajaran matematika yang pada semester sebelumnya dan hasil wawancara dengan guru matematika SP1 termasuk anak yang cukup aktif di kelas dan mampu menyerap materi dengan baik. Hasil kerja SP1 pada kuis dan tes kemampuan pemahaman relasional pada materi relasi dan fungsi memiliki hasil yang baik. Hal ini tampak saat SP1 mampu menunjukkan kemampuannya pada keenam indikator kemampuan pemahaman relasional. Namun SP1 kurang teliti saat mengerjakan soal evaluasi terlihat dengan dari tidak menjawab hasil range pada soal nomor 4. Ketika diwawancara, SP1 juga mampu memberikan alasan yang tepat untuk menjawab pertanyaan atas setiap tindakan yang dilakukan saat mengerjakan soal evaluasi dengan baik, kenapa SP1 menjawab demikian. SP1 juga menjadi pusat berbagai pertanyaan dari anggota kelompoknya dan SP1 mampu menjawab pertanyaan anggota kelompoknya dengan baik dan jelas sehingga terjadi transfer informasi dari SP1 ke siswa lain ataupun dari siswa lain ke SP1.

Prima, Vol. 3, No. 2, Juli 2019, 103-115. 


\section{b. Analisis SP2}

SP 2 merupakan salah satu siswa yang tergolong dalam kategori siswa berkemampuan tinggi di dalam kelas. Hal ini dapat dilihat dari nilai raport siswa pada mata pelajaran matematika yang pada semester sebelumnya dan hasil wawancara dengan guru matematika SP2 cukup aktif di kelas namun kadang SP2 kurang percaya diri atas kemampuannya. Dari hasil kuis dan tes evaluasi pemahaman relasional, SP2 mampu menjawab dengan baik, namun saat mengerjakan soal tentang menggambar grafik, SP2 kurang teliti. Kemampuan menjelaskan masalah juga baik telihat saat mengerjakan soal cerita, SP2 membuat gambar bangun datar seperti yang tertuang dalam soal. SP2 merupakan penggerak diskusi dan meminta teman-temannya untuk fokus pada materi yang sedang dipelajari.

\section{c. Analisis SP3}

SP 3 merupakan siswa yang memiliki kemampuan sedang di dalam kelas. SP 3 agak sedikit pendiam jika dibandingkan dengan SP 1 dan SP 2 yang aktif. SP 3 termasuk siswa yang tekun dan memiliki semangat belajar yang tinggi. Menurut guru matematika SP3 tidak aktif seperti SP1 dan SP2 namun memiliki kemampuan yang baik dalam mengikuti pembelajaran. Selama pembelajaran dengan menggunakan pendekatan PMRI, SP 3 menjadi lebih aktif dalam kegiatan diskusi di kelompoknya dengan membantu teman-teman yang belum memahami materi yang sedang dipelajari. Pada aktivutas pembelajaran, SP 3 mampu melakukan self develop model dan guided reivention. Hasil evaluasi SP3 juga cukup baik, terlihat saat SP3 mampu membuat representasi matematika dalam bentuk diagram panah dan berupa kalimat untuk soal evaluasi nomor 1. Hal ini membuktikan bahwa dengan pendekatan PMRI SP3 mampu meningkatkan pemahaman relasionalnya dengan baik.

\section{d. Analisis SP4}

SP 4 merupakan siswa yang memiliki kemampuan sedang di dalam kelas. SP 4 merupakan anak yang cukup aktif dan mau bertanya tentang kesulitan yang dihadapinya. SP 4 mempunyai semangat belajar yang cukup baik, tekun dan tulisan yang rapih dalam mengerjakan soal kuis dan soal evaluasi. SP4 kurang percaya diri terlihat saat wawancara dia terlihat ragu untuk memberikan alasan atas setiap tindakan yang dilakukannya, namun pemahaman SP4 atas konsep yang pernah dipelajari cukup bagus. Hasil evaluasi SP4 cukup baik dan saat wawancara SP 4 mampu menjelaskan setiap tindakan yang dibuat dengan baik meskipun dengan bahasa yang tersendat karena rasa kurang percaya dirinya atas jawaban yang diberikan. Pembelajaran dengan pendekatan PMRI mampu meningkatkan interaktivitas pada SP4 dan meningkatkan pemahaman relasionalnya dengan baik. 


\section{e. Analisis SP5}

SP 5 merupakan siswa yang memiliki kemampuan rendah di dalam kelas. SP 5 merupakan anak yang cukup aktif di dalam kelas. Menurut guru matematika SP5 memiliki tingkat kepercayaan diri yang tinggi. meskipun kemampuan matematikanya tergolong rendah di kelas, tapi semangat belajarnya cukup baik. Semangat belajarnya ditunjukkan oleh SP 5 saat mewakili kelompoknya untuk mempresentasikan hasil kesimpulan kelompoknya dengan bahasa yang interaktif dengan teman sekelasnya. Hasil evaluasi SP5 cukup baik dengan menjawab semua soal dengan cukup baik. Pembelajaran dengan pendekatan PMRI dapat menumbuhkan kemampuan pemahaman relasional SP5. Penggunaan konteks yang sesuai dengan kehidupan sehari-hari dan dimengerti oleh SP5 membuat SP 5 mudah memahami konsep. SP5 menyatakan bahwa SP5 baru menemukan pembelajaran matematika yang melibatkan siswa dalam menemukan konsep matematika. SP5 sangat menyukai diskusi yang dilakukan dalam kelompok, karena bagi SP5 kegiatan diskusi dapat menjadi sarana tukar informasi antara siswa berkemampuan tinggi dengan siswa berkemampuan rendah.

\section{f. Analisis SP6}

SP 6 mempunyai kemampuan yang kurang baik dan tergolong sebagai siswa yang memiliki kemampuan matematika rendah. Menurut guru matematika SP 6 ini termasuk pasif, suka ragu-ragu dalam memberikan pendapatnya, pendiam di kelas namun cukup memperhatikan apa yang disampaikan oleh guru di depan kelas. Sikap ragu-ragu SP 6 disebabkan rasa kurang percaya diri dalam menyampaikan pendapatnya kepada guru namun masih bisa menyampaikan pendapat kepada temannya. Selama belajar menggunakan pendekatan PMRI, SP 6 cukup baik dalam memperhatikan dan menerima arahan yang disampaikan oleh guru dan mau terlibat dalam aktivitas diskusi kelompok. Kepercayaan diri SP 6 juga sudah terlihat saat SP 6 berani mengeluarkan pendapatnya dan mau mewakili kelompoknya di depan kelas. Hasil evaluasi SP6 cukup baik meskipun belum maksimal karena SP 6 belum maksimal dalam menjawab soal nomor 4 dan 5. Pada nomor 4 belum selesai menjawab karena terkendala pada soal hitungan matematika karena SP6 memang lemah dalam soal hitungan. Pada soal nomor 5 SP6 salah karena kurang teliti dalam mengidentifikasi soal. Dari 6 indikator yang ada, SP 6 belum memenuhi 3 indikator yaitu indikator kemampuan menerapkan konsep secara algoritma, kemampuan menyajikan konsep dalam bentuk representasi matematika dan kemampuan mengaitkan berbagai konsep internal (internal dan eksternal matematika).

Prima, Vol. 3, No. 2, Juli 2019, 103-115. 


\section{SIMPULAN DAN SARAN}

Berdasarkan hasil analisis retrospektif, analisis data, serta penggunaan konteks masalah yang sesuai dengan karakteristik PMRI bermanfaat dalam menjembatani pemahaman antara berbagai kemampuan siswa dalam membangun pemahaman konsep relasi dan fungsi di kelas X SMA Cakra Buana Depok.

Penggunaan konteks Pilkada dimana siswa mengamati hubungan cagub-cawagub yang diusung partai politik dan hubungan partai pengusung dengan cagub-cawagub dengan diagram panah sebagai model of dapat membantu pemahaman siswa tentang konsep relasi dan fungsi sebagai model for serta membantu yang kurang memahami konsep himpunan yang telah dimiliki siswa sebelumnya. Penggunaan konteks Suku-suku yang berawalan huruf T di pulau Sumatera sebagai model of dapat menjembatani siswa dalam menemukan konsep sifat fungsi injektif sebagai model for. Kegiatan pembelajaran dengan interaktivitas pada pertemuan ini cukup baik pada kegiatan diskusi kelas yang difasilitasi dengan beberapa pertanyaan pancingan dari guru kepada siswa untuk mengarahkan siswa menemukan konsep sifat fungsi injektif yang berasal dari konsep fungsi. Konteks Peta Dunia dimana nama-nama negara berawalan huruf A dipasangkan dengan benua dimana letak negara tersebut berada. Konteks ini berhasil dengan siswa membuat diagram panah sebagai model of dan sifat-sifat yang dimiliki dari diagram panah tersebut menjadi model for untuk menemukan sifat fungsi surjektif. Jadwal pertandingan sepak bola Liga Inggris yang digambarkan siswa dalam bentuk diagram panah dan hasil mengamati KTP sebagai model of yang dapat menjembatani siswa dalam menemukan sifat fungsi bijektif sebagai model for. Dari berbagai macam konteks untuk beberapa konsep matematika tersebut dapat diambil kesimpulan bahwa konteks yang tepat yang sesuai konsep materi matematika yang dipelajari memegang penting dalam menjembatani proses pemahaman konsep siswa dari tahap informal yang berasal dari hal yang realistik bagi siswa menjadi konsep matematika formal dalam kegiatan pembelajaran matematika di kelas.

Konstruksi pemikiran yang dilakukan peserta didik di setiap pembelajaran menunjukkan bahwa PMRI menempatkan matematika sebagai suatu proses untuk kegiatan penemuan kembali suatu konsep. Interaktivitas terjadi antara siswa dengan siswa dan antara siswa dengan guru dalam diskusi menyebabkan terjadinya pertukaran informasi yang dapat memperkaya pengetahuan siswa. Dalam pembelajaran dengan pendekatan PMRI, siswa merupakan pusat pembelajaran yang harus terlibat aktif dalam proses penemuan suatu konsep sedangkan guru bertindak sebagai fasilitator yang mengarahkan siswa untuk menemukan 
suatu konsep. Keterkaitan (intertwinment) dalam pembelajaran relasi fungsi bukan hanya keterkaitan antara konsep dalam materi matematika seperti himpunan, bilangan, operasi aljabar namun juga ada keterkaitan dengan ilmu pengetahuan lain di luar matematika seperti dengan pelajaran IPS.

Sebagai penentu keberhasilan proses pembelajaran di kelas, hendaknya guru dapat menggunakan berbagai metode atau pendekatan pembelajaran yang inovatif yang mampu melibatkan siswa secara aktif dalam kegiatan pembelajaran di kelas diantaranya pendekatan PMRI berdampak pada kemampuan siswa tidak hanya mampu memahami konsep melainkan mampu menyelesaikan masalah dalam kehidupan sehari-hari. Guru sebelum melaksanakan pembelajaran di kelas hendaknya terlebih dahulu dapat mendesain pembelajaran yang tepat dan sesuai dengan materi pelajaran yang akan dipelajari serta dapat menggunakan konteks dunia nyata sebagai media untuk membantu siswa memahami dan menemukan konsep matematika. Ruang lingkup yang terbatas, diharapka pada peneliti selanjutnya untuk melakukan penelitian dengan cakupan materi yang lebih luas.

\section{DAFTAR PUSTAKA}

Akker, J Van Den, Koeno Gravemeijer \& Susan McKenney. (2006). Educational Design Research. Oxon: Routledge.

Chubb, Mark. (2016). Focus on Relational Understanding. Accessed on September1, 2017 from https://buildingmathematicians.wordpress.com/2016/07/31/focus-on-relationalunderstanding.

Gravemeijer, Koeno, Paul Cobb. (2006). "Design Research from Learning Design Perspective.” Journal Education Design Research, p.17-51.

Hadi, Sutarto. (2017). Pendidikan Matematika Realistik: Teori, Pengembangan dan Implementasinya. Jakarta: Rajawali Pers.

Jamaliah. (2016). Design Research: Pengembangan Pembelajaran Dengan Pendekatan Matematika Realistik Indonesia untuk Membangun Pemahaman Relasional Siswa pada Materi Lingkaran di Kelas XI IPA SMAI AL AZHAR 1 JAKARTA. Tesis. Program Studi Magister Pendidikan Matematika Universitas Negeri Jakarta, Jakarta.

Mulyana, Novianti. (2015). Design Research: Pengembangan Pembelajaran Dengan Pendekatan Matematika Realistik Indonesia untuk Membangun Pemahaman Relasional Peserta Didik pada Pokok Bahasan Integral di Kelas XI IPS MAN 4 JAKARTA. Tesis. Program Studi Magister Pendidikan Matematika Universitas Negeri Jakarta, Jakarta. 
Oktaria, Marrendy. (2015). Design Research: Pengembangan Pembelajaran Dengan Pendekatan Matematika Realistik Indonesia untuk Membangun Pemahaman Relasional Siswa pada Materi Logaritma di Kelas X AP SMK Prudent School Tangerang. Tesis. Program Studi Magister Pendidikan Matematika Universitas Negeri Jakarta, Jakarta.

Riyanti, Sri. (2011). Pemahaman Relasional. Accessed on October 26 from http://sinriyanti.blogspot.co.id

Wijaya, Ariyadi. (2012). Pendidikan Matematika Realistik Sebagai Suatu Alternatif Pendekatan Pembelajaran Matematika. Yogyakarta: Graha Ilmu. 